\author{
Wojciech BŁAŻEJEWSKI ${ }^{1}$ \\ Adrianna FILIPIAK ${ }^{2}$ \\ Michał BARCIKOWSKI ${ }^{2}$ \\ Karolina LAGODA ${ }^{2}$ \\ Pawel STABLA ${ }^{2}$ \\ Marek LUBECKI ${ }^{2}$ \\ Michał STOSIAK ${ }^{2}$ \\ Cezary ŚLIWIŃSKI ${ }^{3}$ \\ Zbigniew KAMYK ${ }^{3}$
}

\title{
DESIGN AND IMPLEMENTING POSSIBILITIES OF COMPOSITE PONTOON BRIDGE
}

\begin{abstract}
This work focuses on the analysis of actions conducted by the Military Institute of Engineer Technology and Wroclaw University of Science and Technology regarding the production and testing (on proving ground) of composite pontoon bridge. The starting point for this work was the experience gained from the project named „Light, resistant to environmental hazards, aluminum-composite hybrid pontoon used in constructing floating bridges of MLC 70/110 class". Each one of the three $\mathrm{V}$-shaped outriggers was designed using different technology. The middle part was constructed mostly of aluminum by company PREMO, but the smaller outrigger and all parts of the bow were made at Wroclaw University of Science and Technology from composite material reinforced with glass, aramid and carbon fibers. The inside was filled with multiple types of foam. During successful tests on proving grounds, conducted by Military Institute of Engineer Technology, elements were connected with PP-64 pontoons. It was proven that Wroclaw scientific society is capable of designing and manufacturing of a prototype pontoon bridge park.
\end{abstract}

Keywords: pontoon bridge, composite material, prototype

\section{Introduction}

Floating bridges are used for temporary transverses (including military transverses). The oldest object of this kind in Poland was a pontoon bridge built specifically for the march of Polish-Lithuanian army during the Battle of Grunwald preparations. This bridge was constructed of 150 boats and had the total length of approx. $500 \mathrm{~m}$. Built on the edge of Kozieniecka Forest, it was rafted to Czerwińsk

\footnotetext{
${ }^{1}$ Corresponding author/autor do korespondencji: Wojciech Błażejewski, Wroclaw University of Science and Technology, Faculty of Mechanical Engineering, 25 M. Smoluchowskiego Ave., 50-370 Wroclaw, Poland, tel.: (71) 3202765, e-mail: wojciech.blazejewski@pwr.edu.pl

2 Wroclaw University of Science and Technology, Faculty of Mechanical Engineering

${ }^{3}$ Military Institute of Engineer Technology, Wroclaw
} 
and set up in half a day. It allowed for 3 day long march. Floating bridges were built during many following military expeditions in years: 1414 in Zakroczym, 1419 and 1422 in Czerwińsk [1]. These bridges had essential attributes that made them more resistant. These bridges were mobile, easy to fix and disassembly in case of spates. Moreover, these objects did not need construction of expensive foundations. Due to these reasons they were built for years in big trade centers. The most popular structures include four bridges built by the Swedish in 1756 in Warsaw [2], the floating bridge built by the Imperial Russian Army in 1815 in Plock (it existed in the original form until 1895) and 637,48 meter long bridge in Wloclawek (built in 1865) constructed for civilians and used until 1914 (Fig. 1).

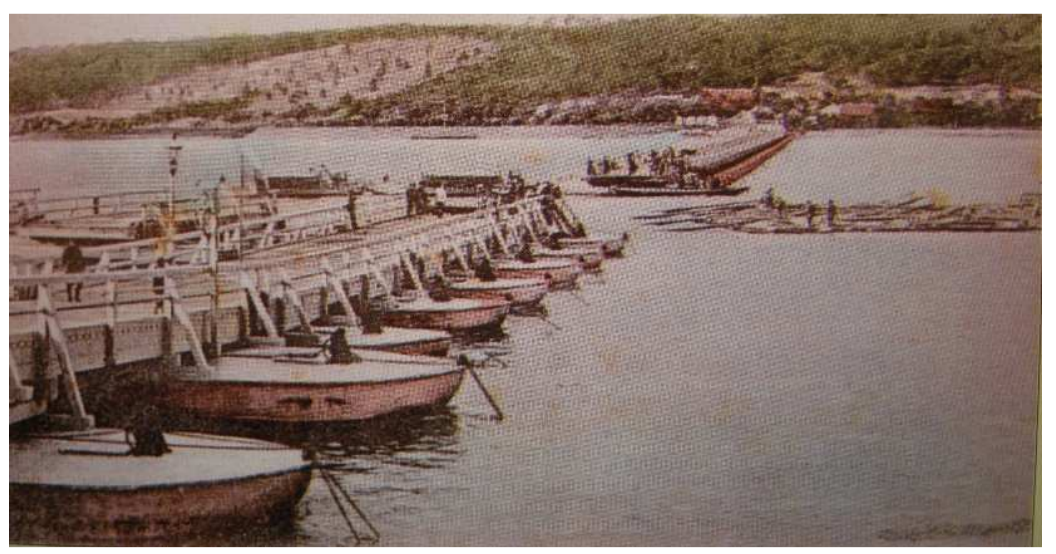

Fig. 1. Bascule pontoon bridge on the Vistula in Wloclawek (photo made before 1914) [3]

The largest modern bridges were built in the USA and Japan, and newest designs include 845 meter long Bergsoysund Floating Bridge (Kristiansund) from 1992 and 1246 meter long Nordhordland Floating Bridge (Salhus) from 1994, both built in Norway $[4,5]$.

\section{New bridges and materials}

Composite bridges have been built for about 30 years. The first objects of this type include the bridge made from polymer composites in China in 1982 (Miyun), the foot-bridge in Scotland from 1992 (Aberfeldy) and the Bonds Mill Lock Bridge in England built in 1994. The usage of fiber reinforced materials is becoming useful in a wide range of applications, as proven by [6-8]. Along with civilian structures, there are numerous bridges built fully from composite materials for military use (mostly for American and Canadian armies) [9-12]. Fundamental advantages of fiber reinforced composite materials in comparison to traditional materials include superior specific resistance, much higher fatigue limit, 
high chemical resistance (to corrosion), resistance to environmental hazards (including UV rays), programmable structure and many more. These attributes are decisive when considering suitability of composite materials in bridge design.

In Poland first bridges made from composite materials are also being built; these include the foot-bridge over the sewage plant in Lodz from 2002, the footbridge over the S11 express road in Gadki from 2008 and the bridge in Błażowa (Rzeszów) form 2015. The latest project, initiated by the Military Institute of Engineer Technology and Wroclaw University of Science and Technology, aims at developing a technology and a manufacturing concept of a light pontoon, used for building temporary bridges. This project has already been implemented and tested, and so far its hypotheses have been proven correct.

\section{Composite pontoon bridge}

Mobile bridges must comply with multiple criteria that adapt them to requirements set for both bridges and cargo that can be transported using multiple means. The expected attributes include low weight, high resistance, simplicity of assembly and compatibility with popular, but legal systems. Due to these reasons, the modern pontoon bridge is designed to maximize the usage of composite materials while maintaining classic structure compliant with the Polish PP-64 type pontoon, as a part of the innovation project no. 03003906, named „Light, resistant to environmental hazards, aluminum-composite hybrid pontoon used in constructing floating bridges of MLC 70/110 class". This first, light segment of the bridge consists of 3 parts forming the so-called „V-shape”. The prototype block was made using 3 parts (Fig. 2), and each of them was manufactured using different technologies to learn and study these innovative solutions. Geometry of the object enables folding and unfolding two wings connected to the central part using a hinge. The folded formation is used for transportation by a trailer attached to a tractor unit (Fig. 3).
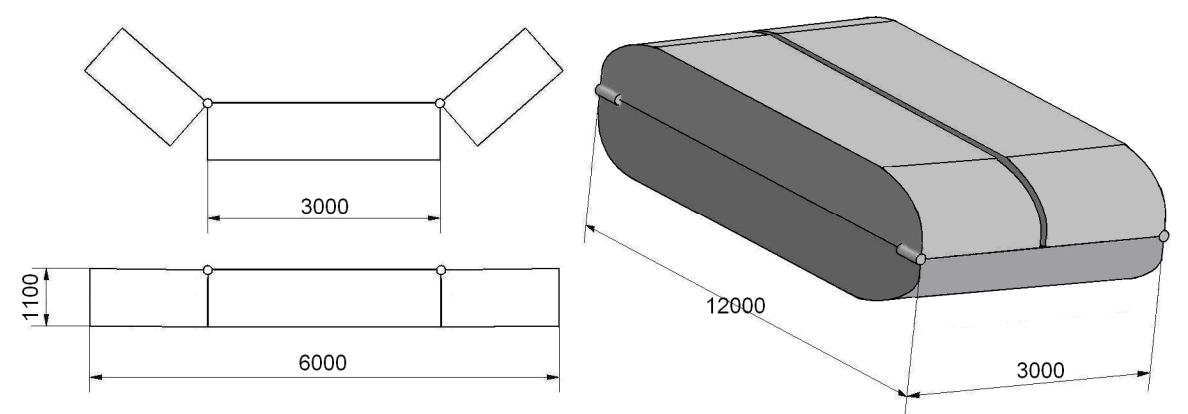

Fig. 2. Concept of three-part „V-shaped” pontoon 


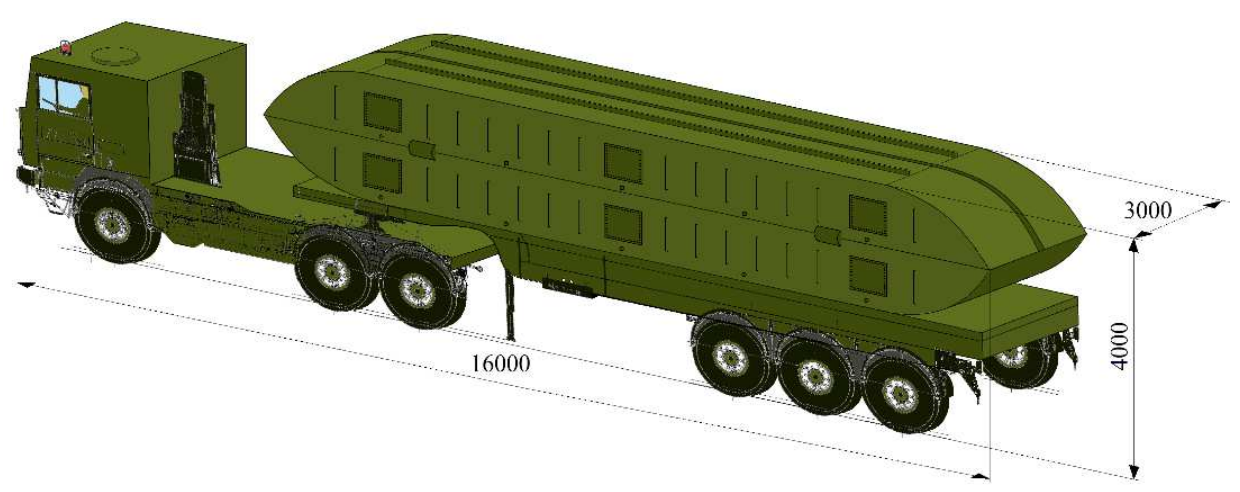

Fig. 3. Concept of pontoon transportation

Hulls of the central part and one of the wings are manufactured using welded aluminum sheets. Inner space is filled with an unsinkable material with closed pores (e.g. Styrofoam). Bow and stern of these parts were made from glass fiber reinforced composite materials with epoxy resin matrix. Pontoons are connected using pins, as defined by PP-64 „Ribbon” system. The third part was designed to be produced fully from composite materials (Fig. 4). It consists of glass, aramid and carbon fibers reinforced composite, filled with construction foam. Such structure assures proper stiffness and resistance to damage. Keel is made of sandwich material and is removable, as expected of this element because of heavy wear.

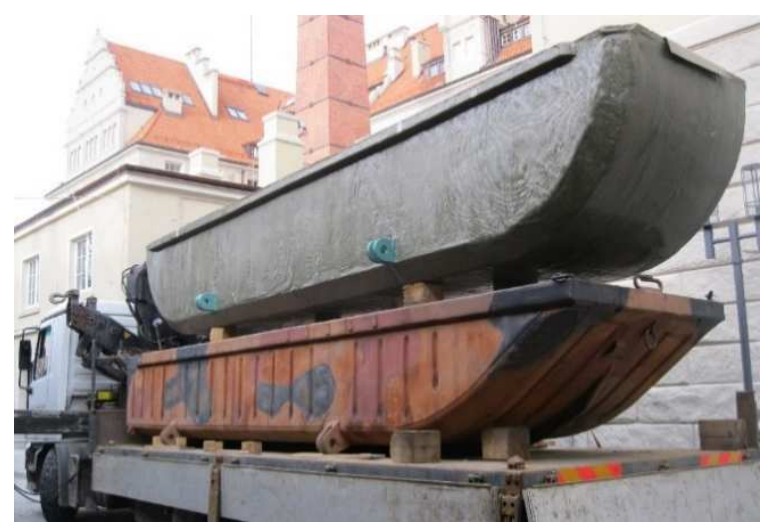

Fig. 4. Two pontoons, PP-64 at the bottom and the prototype made from composites at the top

The structure of a composite pontoon is a spatial structure of sandwich laminate and various types of ribbing as well as foam fillings. The durability of this element has been selected to the nature of the loads occurring during operation in the MLC 70/110 class. The top layer was made of aluminum ribbed plate to achieve adequate grip of vehicle wheels and to ensure resistance to abrasion. This surface is an integral part of the pontoon, therefore laboratory tests of its samples (Fig. 5) were carried out on a fragment of its section [13]. 


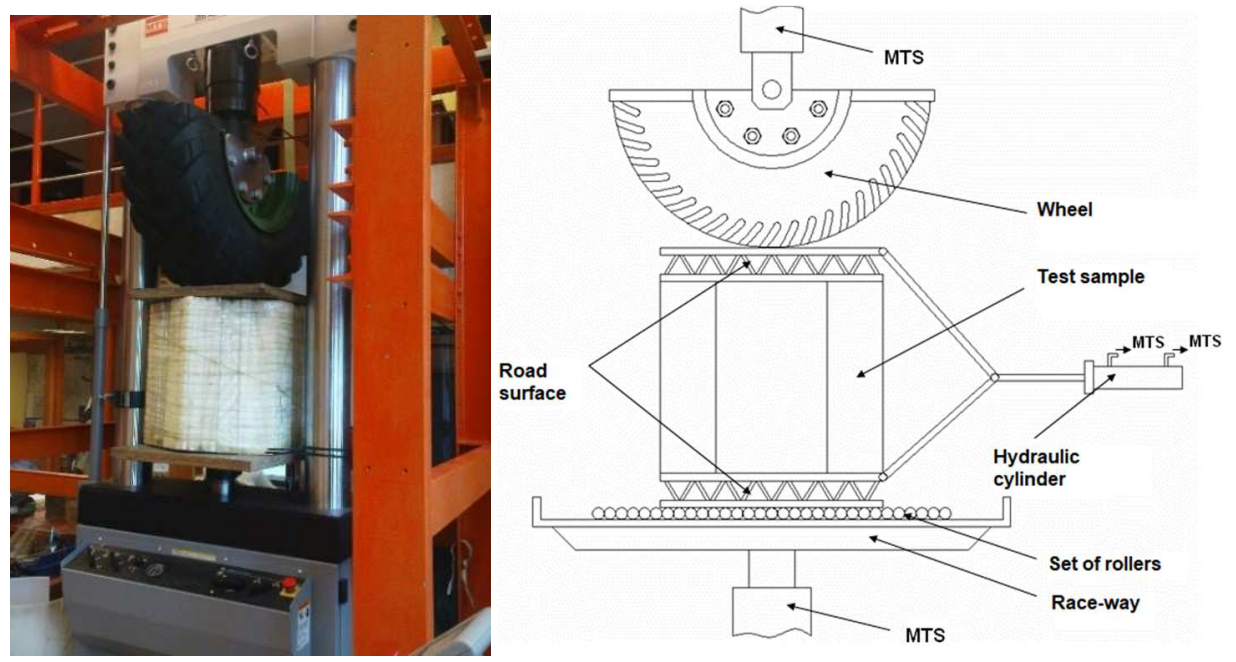

Fig. 5. The original station for testing the elements of a block pontoon

Dry tests were also carried out. Dry strength tests consisted in loading the middle float, which was suspended on external floats. The outer ones were based on sand. Measurements of displacements of control points were carried out using two structural light scanners, with an accuracy of approx. $0.1 \mathrm{~mm}$.

\section{Technical parameters of the pontoon}

Requirements for pontoon bridges are complex. In terms of operational loads, it is necessary to adapt the design to both military (NATO [14]) and civil (Polish Standard [15]) requirements. In terms of military loads, the pontoon should meet the requirements of the recommended MLC 70/110 class. Its name indicates the weight of a vehicle moving on the bridge: $70 \mathrm{t}-$ e.g. a tracked vehicle, $110 \mathrm{t}-$ a wheeled vehicle (semi-trailer tractor). The nature of the interactions of both types of vehicles is different. Considering the global load of the object, it can be concluded that tracked vehicles are heavy but have a large pressure area. In the case of wheeled vehicles, the suitability of the site is the local resilience of the surface. The MLC 70/110 class determines the axle load of $309.7 \mathrm{kN}$. Platform elements are loaded with a force of $90.7 \mathrm{kN}$ per the area of $0.4 \times 0.5 \mathrm{~m}$. In turn, the load on a tracked vehicle is generated by a force of $317.5 \mathrm{kN}$ spread over the area of $4.57 \times 0.79 \mathrm{~m}$ [6]. A prototype pontoon was designed and made for such loads based on the requirements of the ordering party (DPZ MON) and the defense standard [16].

The durability of the pontoon, according to the standard assumptions, should be 30 years. Over this period, there may be 5,000 MLC 70/110 vehicles passing. The maximum number of individual tractor and trailer wheels in each of them is 10. For this reason, the pontoon surface should withstand 25,000. fatigue load 
cycles, so its strength can be considered low-cycle. The durability of the pontoon bridge will also be determined by the simplicity and the method of its assembly. A positive feature of the composite construction in comparison to the standard PP64 segment is the maintenance of its buoyancy in the case of even significant unsealing of the skin (piercing or breaking the fragment.) An additional benefit is the possibility of repairing damage using handheld tools.

\section{Polish prototype composite pontoon}

The presented composite pontoon was made with collaboration of the Military Institute of Engineering Technology (WITI) and Wroclaw University of Technology. During the tests of the finished prototype, in 2012 the pontoon segments were launched and connected to the pontoons of the Polish military bridge PP-64 (Fig. 6). The military belt of various masses, including Star 266, the prototype demounting vehicle and the prototype Wheel Transport Engineer Reconnaissance weighing over 25 tons, passed through the ribbon (Fig. 7). The bridge successfully withstood the passage of the abovementioned vehicles, meeting the operational requirements.
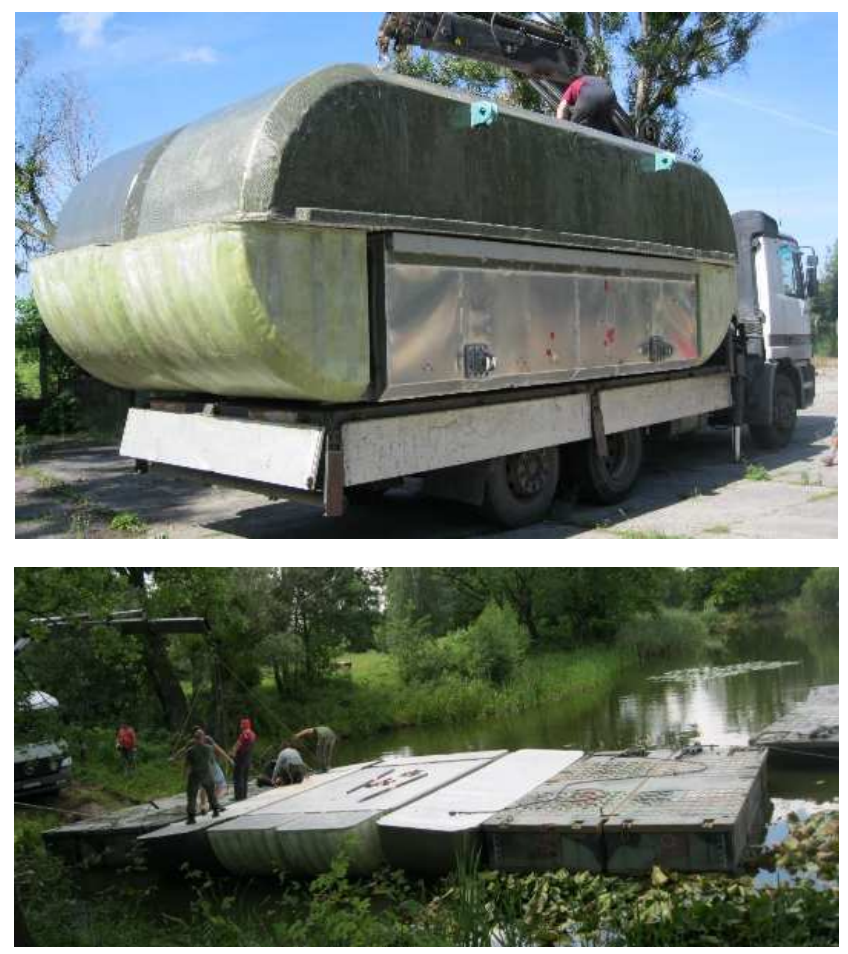

Fig. 6. Segment transport and construction of the crossing in combination with PP-64 segments 


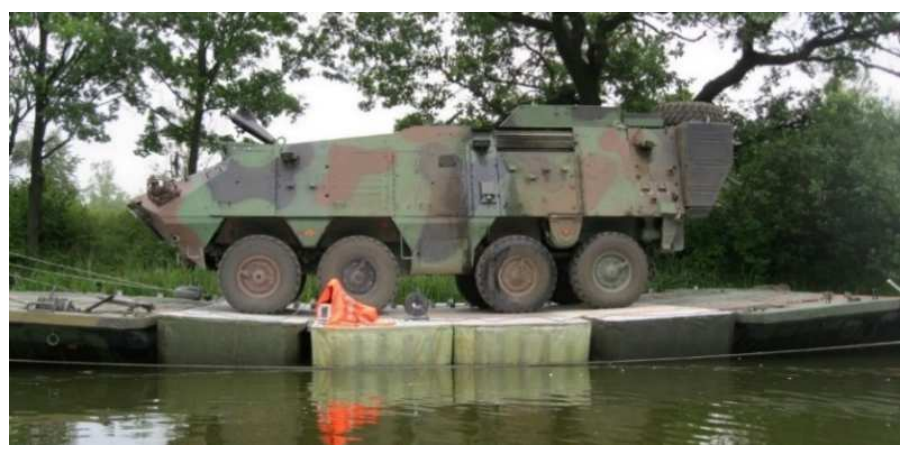

Fig. 7. Water trials

Tests of operational loads were also performed by measuring the displacement of the row of points for the central segment located on the edge and on the axis of the road (Fig. 8 and Fig. 9). For measuring the displacements, during bridge loading, a structural light scanner was used. The test object was loaded with vehicles of various weights: Star 266 ( 7.5 tons), Ryś (25 tons). Table 1 shows the value of averaged vertical displacement and the increase in buoyancy depending on the loading vehicle. Please observe that the buoyancy increase is lower than the weight of the vehicle as some of that weight is taken also by neighboring, linked pontoons in the bridge.

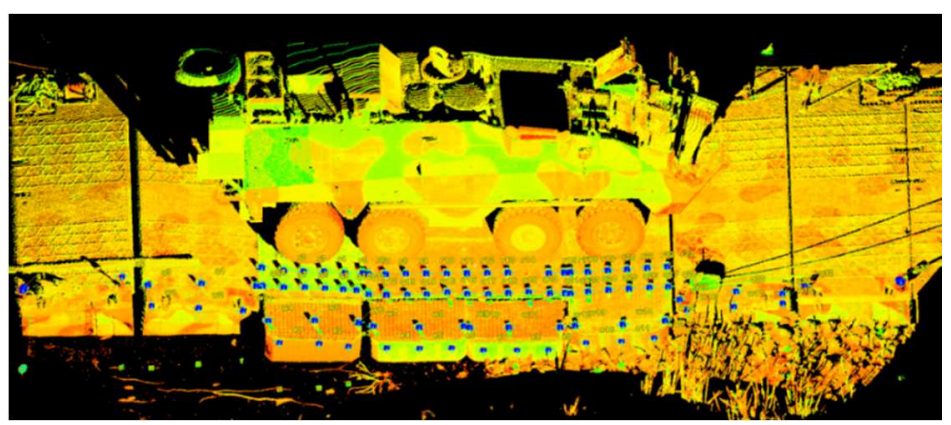

Fig. 8. Vertical displacements of the central segment of the bridge

Table 1. Results of tests of operational loads for various vehicles

\begin{tabular}{|l|c|c|}
\hline \multicolumn{1}{|c|}{ Vehicle } & Averaged vertical displacement, $\mathrm{m}$ & Increase of buoyancy, Mg \\
\hline Star 266 (7.5 tons) & 0.16 & 6.29 \\
\hline Ryś (25 tons) & 0.48 & 18.57 \\
\hline
\end{tabular}



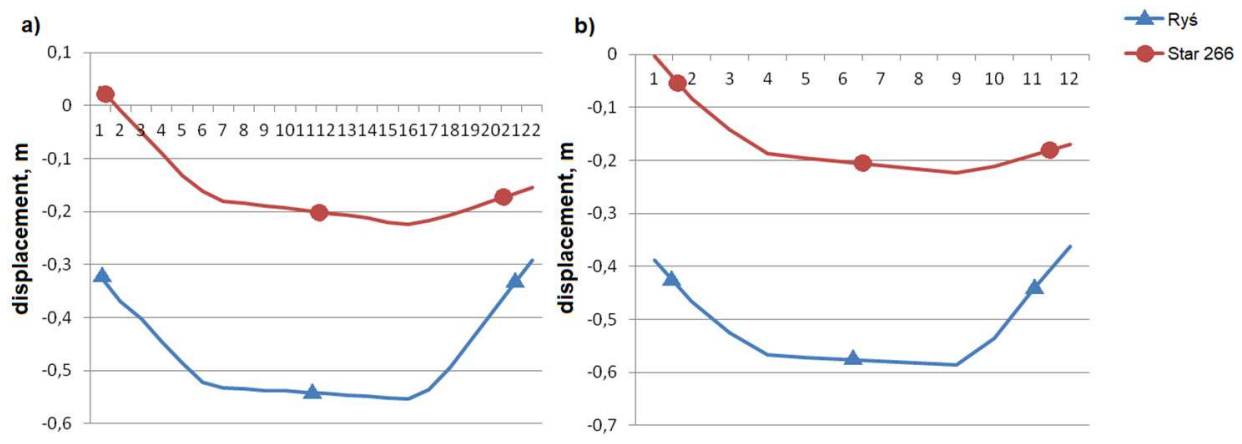

Fig. 9. Displacements of marker points: a) the nearest axis of the road, b) on the edge of the road

\section{Summary}

During the cross-border inspections, potential damage was monitored using fiber optic sensors. The bridge successfully managed to pass the abovementioned tests. No damage to the spans or exceeding the buoyancy reserve was found. The tests of displacement of bridge elements under the load of the abovementioned vehicles with the use of a spatial scanner were also carried out. As a part of the work on the pontoon, many other tests have been carried out, e.g. measurement of strains using strain gauges during tests on suitably shaped sand heaps, numerous tests of the technology of making further elements, strength tests of internal nodes, etc. The presented research has shown that it is possible to use polymer composites in construction of military bridges and mobile composite bridge structures. The use of composites in bridges, both military and civil, gives unique advantages resulting from the specific strength of these materials compared to steel and aluminum, as well as the best corrosion resistance - resistance to atmospheric exposure during storage. Therefore, polymer composites have a bright future in bridge engineering.

The presented Polish pontoon bridge is a structure that shows unique advantages of durability and safety of use resulting mainly from the use of modern composite materials that ensure corrosion resistance, high strength and low weight while maintaining a reasonable cost of performance. The example of a new pontoon confirms the suitability of the applications of polymer composites in bridge engineering. It is also a proof of the positive impact of technical university cooperation with the Polish army's design and research unit.

\section{References}

[1] Chwaściński B.: Mosty na Wiśle i ich budowniczowie, Warszawa 1997.

[2] Sterner W.: Mosty Warszawy, PWT, Warszawa 1960.

[3] Kaliszewski K., Rojewski T., Winiarski A.: Ukłony z Włocławka, karty pocztowe 1898-1945, EXPOL, Włocławek 2005. 
[4] Watanabe E., Wang C.M., Utsunomiya T., Moan T.: Very Large Floating Structures: Applications, Analysis and Design. Centre for Offshore Research and Engineering National University of Singapore. CORE Report No. 2004-02.

[5] Watanabe E., Utsunomiya T.: Analysis and design of floating bridges, Progress Structural Eng. Mater., 5 (2003) 127-144.

[6] Bank L.C.: Application of FRP composites to bridges in the USA. Int. Colloquium on Application of FRP to Bridges, Japan Society of Civil Engineers, S. Yamada, ed., Tokyo, Japan 2006, pp. 9-16.

[7] Keller T.: Overview of fiber-reinforced polymers in bridge construction, Struct. Eng. Int., 12 (2002) 66-70.

[8] Zobel H., Karwowski W., Sarnowska J., Wróbel M.: Nowa generacja mostów - mosty z kompozytów polimerowych, część I - Autostrady 4/2004, s. 16-19, część II Autostrady 5/2004, s. 54-63.

[9] Kamyk Z., Szelka J.: Zastosowanie kompozytów w mostach wojskowych, Archiwum Instytutu Inżynierii Lądowej, 5 (2009) 133-142.

[10] Robinson M.J., Kosmatka J.B.: Light-weight fiber-reinforced polymer composite deck panels for extreme applications, J. Composites Constr., 12 (2008) 344-354.

[11] Robinson M.J., Kosmatka J.B.: Development of a short-span fiber-reinforced composite bridge for emergency response and military applications, J. Bridge Eng., 7 (2008) 388-397.

[12] Wight R.G., Shyu C.T., Tanovic R., Erki M.A., Heffernan P.J.: Short-span deployable GFRP tapered box beam bridge, Proc., 4th Int. Conf. on Advanced Composite Materials in Bridges and Structures. 2004, pp. 20-23.

[13] Błażejewski W., Gąsior P.P., Kaleta J., Krzyżak A., Rybczyński R.: Wytwarzanie i badania sześciokątnych profili kompozytowych do bloków komórkowych, [In:] Materiały polimerowe, T. Spychaj, S. Spychaj (ed.), Szczecin 2010, pp. 117-118.

[14] STANAG 2021, Military Load Classification of Bridges, Ferries, Rafts and Vehicles, NATO NSA, Brussels 2006.

[15] PN-85/S-10030, Obiekty mostowe. Obciążenia.

[16] 1NO-54-A201A1 2007, Parki pontonowe. Wymagania ogólne.

\section{MOŻLIWOŚCI PROJEKTOWE I WYKONAWCZE KOMPOZYTOWEGO MOSTU PONTONOWEGO}

\section{Streszczenie}

W ramach projektu rozwojowego nr 03003906 zespoły Wojskowego Instytutu Techniki Inżynieryjnej i Politechniki Wrocławskiej zaprojektowały i wykonały pierwszy w świecie, całkowicie kompozytowy ponton przeznaczony do budowy mostów pływających. Kompletny prototypowy zespół pontonowy składa się z trzech członów zespolonych w układzie „V” - szerokiego członu centralnego i dwóch dwukrotnie węższych członów bocznych. Człony boczne do transportu składają się zawiasowo na wierzch członu centralnego. Każdy z trzech członów wykonano według różnej technologii. Jeden z nich - całkowicie kompozytowy - wykonano, wykorzystując włókna szklane, węglowe, aramidowe oraz wiele różnego typu pianek. Ponton jest lekki, niezatapialny, o podwyższonej odporności na uszkodzenia mechaniczne, w tym odłamki i przestrzelenie, a także na ogień. 
W ostatnim etapie prac ponton włączono w przeprawę i testowano przez najeżdżanie kolejno cięższymi pojazdami wojskowymi. Udowodniono słuszność koncepcji wykorzystania materiałów kompozytowych do budowy pontonów.

Słowa kluczowe: most pontonowy, materiał kompozytowy, prototyp

DOI: $10.7862 / \mathrm{rm} .2018 .35$

Otrzymano/received: 24.04 .2018

Zaakceptowano/accepted: 28.09.2018 